\title{
Magellan Bryozoa: a review of the diversity and of the Subantarctic and Antarctic zoogeographical links*
}

\author{
H.I. MOYANO G. \\ Departamento de Zoología, Universidad de Concepción, Casilla 160-C, Concepción, Chile
}

\begin{abstract}
SUMMARY: Based principally on previous work by the author, the Magellan Bryozoa are reviewed in terms of endemism, specific diversity, zoarial diversity and polymorphism. The Magellan, Atlantic, Pacific, Subantarctic and Antarctic zoogeographical relationships are reevaluated. New data related to the distribution of Magellanic and Antarctic species along the archipelagos of the Scotia Arc and new data on Bryozoa from the Magellan continental slope are added.

Key words: Bryozoa, diversity, polymorphism, endemism, zoogeography, Magellan area, Antarctica, southern Pacific Ocean.

RESUMEN: BRYOZOA MAGALLÁNICOS: REVISIÓN DE LA DIVERSIDAD Y DE LAS CONEXIONES ZOOGEOGRÁFICAS ANTÁRTICAS Y SUBANTÁRTICAS. - Se revisa la briozoofauna magallánica en términos de endemismo, diversidad específica, diversidad zoarial y de polimorfos. Se reevalúan las relaciones zoogeográficas transpacíficas, transatlánticas, subantárticas y antárticomagallánicas. A la revisión anterior basada en trabajos previos del autor se añaden nuevos datos referentes a la briozoofauna magallánica del talud y a la vicariancia entre especies antárticas y magallánicas. Se evalúa el papel del Arco de Escocia en el movimiento de especies desde y hacia la Antártida.
\end{abstract}

Palabras clave: Bryozoa, diversidad, polimorfismo, endemismo, zoogeografía, área magallánica, Antártida, Pacífico austral.

\section{INTRODUCTION}

Knowledge of the Chilean bryozoan fauna began in the Magellan Region, South America, during the first quarter of the $19^{\text {th }}$ century (Lamouroux, 1825). It increased greatly at the end of that century and the beginning of the $20^{\text {th }}$ century with the arrival of many European expeditions to the Southern Ocean, the "Challenger" expedition being the principal one. American and European expeditions to the Antarctic have been steadily completing that knowledge; detailed bibliographic accounts have been provided

\footnotetext{
*Accepted February 26, 1999.
}

by Hastings (1943), Borg (1944), Moyano (1982, 1991) and Hayward (1995).

Zoogeographically the Magellan bryozoan fauna is closely related to that of the Falkland, Tristan da Cunha and Kerguelen archipelagos to the east; a little less to that of the Scotia Arc archipelago and the Antarctic Peninsula to the south and, less related but still sharing several common species, with that of New Zealand and Australia to the west and that of the Chilean coast influenced by the Humboldt cold current to the north. These zoogeographical links are of the vicariant type especially in relation to Antarctica but also sharing species that have Subantarctic or cold-temperate distributions. These types of links 
are respectively caused by the proximity of the southern tip of South America and western Antarctica during the Tertiary and the West Wind Drift circulation connecting the coasts of the austral lands in the Recent.

This work aims to briefly update what is known of the Magellan bryozoan fauna, and to reassess the zoogeographical connections, especially those linking the Magellan bryozoan fauna with that of the Antarctic Peninsula through the Scotia Arc archipelagos.

\section{MATERIAL AND METHODS}

This work has used previously known bryozoan information from the Antarctic and Subantarctic areas (Hastings, 1943; Borg, 1944; Moyano, 1982, 1991, 1995, 1996; Hayward, 1995) for evaluating the zoogeographical significance of the Scotia Arc archipelagos. Data have also been obtained from a) the preliminary taxonomic study of the bryozoan samples gathered by R/V "Victor Hensen" in the Magellan area in October-November 1994, b) the results of the Italian 1991 Magellano I expedition (Moyano, 1992, 1994a,b; Cáceres and Moyano, $1992,1994)$ and c) the partial study of two very rich samples dredged on the continental slope near Cape Horn by R/V “Polarstern” in 1996 (Moyano, 1997).

\section{RESULTS}

\section{Taxonomic diversity}

The Magellan bryozoan fauna accounts for at least 200 species, only slightly less than the species richness at the Antarctic Peninsula and much more than that of the Chilean coast influenced by the cold Humboldt current. Taxonomic richness - including the cyclostome, ctenostome and cheilostome bryozoans- reaches $205 \mathrm{spp}$. (Table 1) and proves to be higher at the generic and familial levels than those of the Antarctic Peninsula and central and northern Chile. Important qualitative differences exist among those three bryozoan faunas: ctenostomes, almost absent from Antarctica, reach 7\% in Magellan South America and 8\% in central and northern Chile; and cyclostomes are proportionally more important and diverse in the Magellan area (Table 1).

Diversity (as E, see Table 1) of the Magellan bryozoan fauna, as a measure of the number of species per genus and the number of species per family, is intermediate among the values calculated for the

TABLE 1. - Diversity and endemism of the Magellan Bryozoa fauna in comparison with those of the Antarctic and central and northern Chile

\begin{tabular}{|c|c|c|c|c|c|c|c|}
\hline \multirow{2}{*}{\multicolumn{2}{|c|}{$\begin{array}{l}\text { General diversity** } \\
\text { (Moyano,1996)* }\end{array}$}} & \multicolumn{2}{|c|}{ Taxonomic richness } & \multirow[b]{2}{*}{ Fam. } & \multicolumn{3}{|c|}{$\mathrm{E}=\mathrm{H}^{\prime} / \mathrm{H}^{\prime} \max 100 * * *$} \\
\hline & & Spp. & Gen & & DSG & DGF . & DSF \\
\hline Antarctic Peninsula & $\mathrm{Ch}, \mathrm{Cy}, \mathrm{Ct}$ & 225 & 102 & 44 & 91.60 & 94.30 & 88.94 \\
\hline Magellan Region & $\mathrm{Ch}, \mathrm{Cy}, \mathrm{Ct}$ & 205 & 106 & 55 & 94.26 & 94.50 & 91.16 \\
\hline Central-Northern Chile & $\mathrm{Ch}, \mathrm{Cy}, \mathrm{Ct}$ & 127 & 79 & 35 & 96.04 & 92.65 & 91.70 \\
\hline \multicolumn{2}{|c|}{$\begin{array}{l}\text { Ordinal diversity***** } \\
\text { (Moyano, 1995) }\end{array}$} & Spp. & CT (\%) & & \multicolumn{2}{|c|}{$\mathrm{CH}(\%)$} & \\
\hline \multirow{3}{*}{\multicolumn{2}{|c|}{$\begin{array}{l}\text { Antarctic Peninsula } \\
\text { Magellan Region } \\
\text { Central-Northern Chile }\end{array}$}} & 203 & $2(0.98)$ & & \multirow{3}{*}{\multicolumn{2}{|c|}{$\begin{array}{r}171(84.24) \\
139(70.92) \\
88(83.02)\end{array}$}} & \\
\hline & & 196 & $14(7.14)$ & & & & \\
\hline & & 106 & $8(7.55)$ & & & & \\
\hline \multicolumn{2}{|l|}{$\begin{array}{c}\text { Endemism } \\
\text { (Moyano, 1995) }\end{array}$} & Spp. & Non-endemic (\%) & \multicolumn{2}{|c|}{ Endemic (\%) } & & \\
\hline \multirow{3}{*}{\multicolumn{2}{|c|}{$\begin{array}{l}\text { Antarctic Peninsula } \\
\text { Magellan Region } \\
\text { Central-Northern Chile }\end{array}$}} & 203 & $33(18.29)$ & \multirow{3}{*}{\multicolumn{2}{|c|}{$\begin{array}{r}170(83.75) \\
107(54.59) \\
40(37.73)\end{array}$}} & & \\
\hline & & 196 & $89(45.41)$ & & & & \\
\hline & & 106 & $66(62.26)$ & & & & \\
\hline
\end{tabular}

$\mathrm{Ch}=$ Cheilostome bryozoans; $\mathrm{Cy}=$ Cyclostome bryozoans; $\mathrm{Ct}=$ Ctenostome bryozoans;

$\mathrm{DSG}=$ Species/genus diversity $; \mathrm{DGF}=$ Genera/family diversity; DSF = Species/family diversity.

* Data not fully worked for ordinal diversity and endemism, therefore for this account previous data by Moyano (1995) have been included in the Table; ** General diversity refers to the entire bryozoan fauna without distinction between the species belonging to three recent orders; *** For theory and calculations of H' and E (evenness) see Cox (1967) and Shannon and Weaver (1963); **** Ordinal diversity or order diversity refers to the species richness of each of the recent orders of the phylum Bryozoa. 
TABLE 2. - Zoarial and zooidal diversity of the Magellan bryozoans in comparison with those of the Antarctic and central-northern Chile. $\mathrm{Fz}=$ Zoarial forms

\begin{tabular}{|c|c|c|c|c|c|}
\hline $\begin{array}{l}\text { Zoarial diversity } \\
\text { (Moyano, 1995) }\end{array}$ & N (spp.) & $\mathrm{Fz}$ & $\mathrm{H}^{\prime}$ & H'max. & E (H'/H'max. 100) \\
\hline $\begin{array}{l}\text { Antarctic Peninsula } \\
\text { Magellan Region } \\
\text { Central-Northern Chile }\end{array}$ & $\begin{array}{l}203 \\
196 \\
106\end{array}$ & $\begin{array}{r}10 \\
10 \\
6\end{array}$ & $\begin{array}{l}2.5512 \\
1.8361 \\
1.1272\end{array}$ & $\begin{array}{l}3.3219 \\
3.3219 \\
2.5849\end{array}$ & $\begin{array}{l}76.80 \\
55.27 \\
43.61\end{array}$ \\
\hline $\begin{array}{l}\text { Polymorphs } \\
\text { (Cheilostomatida) (Moyano, 1995) }\end{array}$ & Spp. & None $(\%)$ & One $(\%)$ & Two(\%) & Three (\%) \\
\hline $\begin{array}{l}\text { Antarctic Peninsula } \\
\text { Magellan Region } \\
\text { Central-Northern Chile }\end{array}$ & $\begin{array}{r}171 \\
138 \\
87\end{array}$ & $\begin{array}{l}38(22.22) \\
36(26.09) \\
36(41.38)\end{array}$ & $\begin{array}{l}77(45.03) \\
66(47.83) \\
43(49.42)\end{array}$ & $\begin{array}{c}34(19.88) \\
31(22.46) \\
5(5.75)\end{array}$ & $\begin{aligned} 22 & (12.86) \\
5 & (3.62) \\
3 & (3.45)\end{aligned}$ \\
\hline
\end{tabular}

bryozoan faunas of the Antarctic and central-northern Chile, and is higher when it is calculated for the number of genera per family. The ca. $50 \%$ of endemism of the Magellan bryozoans intermediates between those of the Antarctic (>80\%) and the north and central coast of Chile $(<40 \%)$.

\section{Zoarial forms and polymorphs}

Diversity in zoarial forms of the Magellan bryozoan fauna (10 different types) is similar to that of Antarctica (Table 2) and largely surpasses that of central-northern Chile. The shape diversity, considered as the proportional representation of each zoarial form in the total number of species and measured as evenness, decreases following the geographical gradient from Antarctica to Magellan region and central-northern Chile. Thus, in the Antarctic bryozoan fauna all zoarial forms tend to be represented by a similar number of species whereas in the Magellan and central-northern Chile bryozoan faunas a few zoarial forms tend to predominate: e. g. in the latter more than $50 \%$ of species are encrusting.

The most specialized polymorphs - avicularia and vibracularia - are missing in a fourth of the Magellan cheilostomes and a little less in the Antarctic forms, which contrasts with the higher proportion of bryozoan species lacking polymorphs in central-northern Chile (Table 2).

Considering all types of polymorphs, the percentage of species having only one ranges from $45 \%$ to $49 \%$. That of those with two polymorphs per species is higher in the Magellan bryozoan fauna but less amongst bryozoans from central-northern Chile. Those species having three different polymorphs stand out in the Antarctic bryozoan fauna with more than $12 \%$. This distribution might indicate that
Antarctic waters are inhabited by more K-selected taxa, and that $r$-selected ones are more numerous in central northern Chile. In other words specialization in "exotic castes" of zooids is higher among Antarctic bryozoan species and much lower among those of central-northern Chile.

\section{Bryozoogeographical links}

\section{Transpacific links}

Although distances between the eastern and western coasts of the South Pacific are huge, many common marine organisms inhabit them, viz. the king crab Lithodes murrayi Henderson, 1888, the anguilliform fish Genypterus blacodes (Schneider, 1801), the laminarial algae Macrocystis pyrifera (Linnaeus) C. Agardh, 1820 and Durvillea antarctica (Chamisso in Choris) Hariot, 1892 among many others. The same pattern is observed among bryozoans with not less than 30 species distributed both in Magellan South America and the Australian-New Zealand realm (Table 3 ). Most of these species are strictly austral Pacific excepting those with a much wider distribution such as Microporella ciliata, Beania magellanica and Chaperia acanthina (see Moyano, 1996).

\section{Atlantic-Indian links}

Subantarctic waters flowing eastward and northward from east of Tierra del Fuego explain the existence of the Magellan fauna along the Patagonian continental shelf as far as the latitude of the mouth of the Rio de La Plata (Busk, 1884; López-Gappa and Lichtschein, 1988). The probable northernmost incursion of Subantarctic waters in the southwestern 
TABlE 3. - Common bryozoan species - including cosmopolite forms - linking the Magellan area with the southwestern Pacific. Data from Gordon $(1984,1986,1989)$ and Moyano (1991).

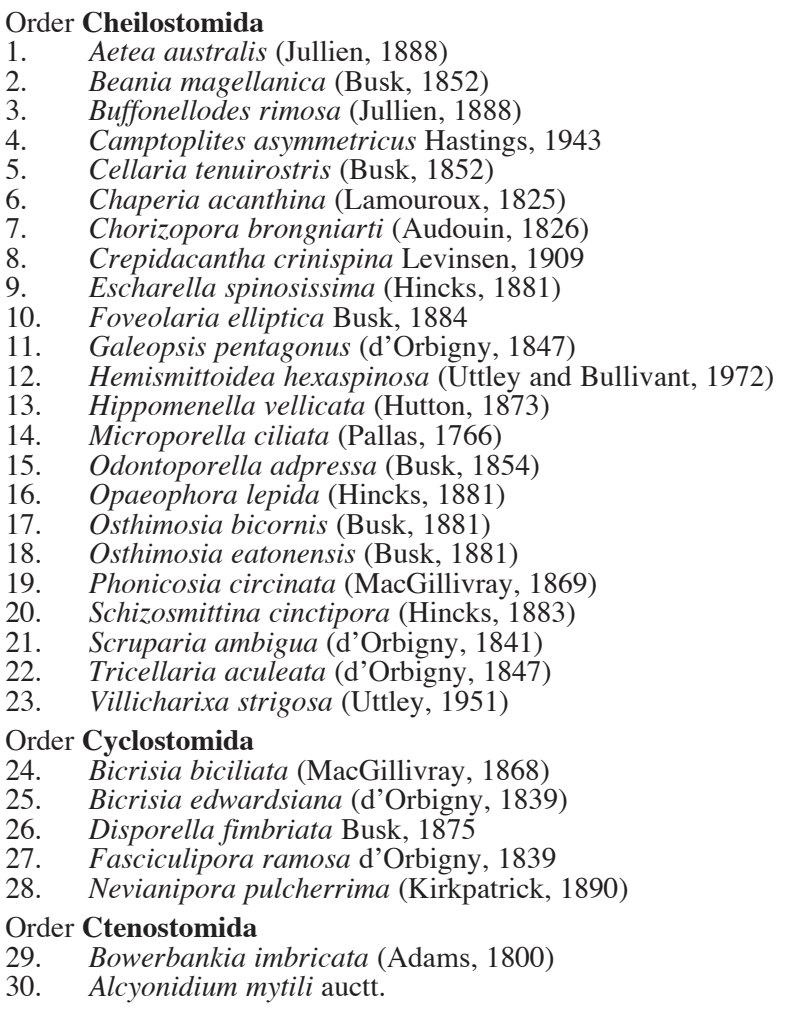

Atlantic Ocean should explain the presence of Subantarctic (Magellan) species around Tristán da Cunha and Gough (Hastings, 1943; Moyano, 1982). Following Subantarctic waters eastward into the Indian Ocean between $45^{\circ} \mathrm{S}$ and $55^{\circ} \mathrm{S}$ three archipelagos are found: Prince Edward, Crozet and Kerguelen. Their bryozoan faunas show a mixture of
Magellan and Antarctic species (Hastings, 1943; d'Hondt and Rédier, 1977; d'Hondt, 1979) with a slight prevalence of Magellan ones sensu Moyano (1982).

\section{Antarctic-Magellan links}

Antarctic-Magellan bryozoogeographical connections are qualitatively and quantitatively different from the trans-Pacific ones. On the one hand there exists an important number of vicariant species (Table 4), and on the other there are common species distributed along the archipelagos of the Scotia Arc (Table 5).

The fifteen species pairs of Table 4 do not actually represent the true richness of vicariant forms because to one Magellan species of a given genus might correspond several Antarctic ones of the same genus or vice-versa. So, whereas to Parafigularia magellanica corresponds the Antarctic P. discors, to the Pagatonian Tertiary fossil Adelascopora divaricata correspond A. jeqolqa Moyano, 1989 and A. secunda from the Antarctic, and to the Magellan Orthoporidra petiolata reciprocate the three Antarctic forms of the genus: $O$. brachyrhyncha Moyano, 1975, O. compacta Waters, 1904 and O. stenorhyncha. This suggests several vicariant events between South America and Antarctica or amongst previously detached lands now forming part of the whole Antarctic Continent.

Species in Table 5 may be considered common to Magellan South America and western Antarctica. According to the directions of arrows most species $($ marked +$)$ seem to be moving from north to south, from Patagonia to the Antarctic Peninsula, ten species seem to go north from Antarctica (marked -) and three

TABLE 4. - Magellan and Antarctic vicariant bryozoan species.

\begin{tabular}{|c|c|c|}
\hline & MAGELLAN & ANTARCTIC \\
\hline 1. & Adelascopora divaricata (Canu, 1904) & A. secunda Hayward and Thorpe, 1888 \\
\hline 2. & Arachnopusia monoceros (Busk, 1854) & A. decipiens Hayward and Thorpe, 1888 \\
\hline 3. & Austroflustra australis López-Gappa, 1982 & A. vulgaris (Kluge, 1914) \\
\hline 4. & Cellarinella dubia Waters, 1904 & C. foveolata Waters, 1904 \\
\hline 5. & Chondriovellum angustilobatum (Moyano, 1974) & Ch. adeliense (Livingstone, 1928) \\
\hline 6. & Exochella longirostris Jullien, 1888 & E. avicularis Hayward, 1991 \\
\hline 7. & Fenestrulina horrida Moyano, 1985 & F. rugula Hayward and Ryland, 1990 \\
\hline 8. & Hippadenella margaritifera (Quoy and Gaimard, 1824) & H. inerma (Calvet, 1909) \\
\hline 9. & Klugella buski Hastings, 1943 & K. echinata (Kluge, 1914) \\
\hline 10. & Micropora notialis Hayward and Ryland, 1993 & M. brevissima Waters, 1904 \\
\hline 11. & Orthoporidra petiolata (Waters, 1905) & O. stenorhyncha Moyano, 1985 \\
\hline 12. & Paracellaria cellarioides Hayward and Thorpe, 1989 & P. calveti (d'Hondt, 1984) \\
\hline 13. & Parafigularia magellanica (Calvet, 1904) & P. discors (Hayward and Taylor, 1984) \\
\hline 14. & Romancheina labiosa (Busk, 1854) & R. asymmetrica Moyano, 1975 \\
\hline 15. & Turritigera stellata Busk, 1884 & T. cribrata Hayward, 1993 \\
\hline
\end{tabular}


TABLE 5. - Scotia Arc archipelagos as a linking way for Magellan and Antarctic bryozoan faunas.

\begin{tabular}{|c|c|c|c|c|c|c|c|c|c|c|c|c|c|}
\hline & \multirow[t]{2}{*}{ SPECIES } & \multicolumn{5}{|c|}{ MAGELLAN } & \multicolumn{7}{|c|}{ ANTARCTIC } \\
\hline & & $\mathrm{TF}$ & $\mathrm{Pa}$ & $\mathrm{Ma}$ & $\mathrm{BB}$ & $\mathrm{KG}$ & $\mathrm{R}$ & GS & OS & $\mathrm{SS}$ & PA & MR & \\
\hline 1. & Aimulosia australis Jullien, 1888 & $\mathrm{x}$ & $\mathrm{x}$ & $\mathrm{x}$ & $\mathrm{x}$ & - & $\mathrm{k}$ & $\mathrm{x}$ & $\mathrm{x}$ & $\mathrm{x}$ & - & - & + \\
\hline 2. & Amastigia gaussi (Kluge, 1914) & - & $\mathrm{x}$ & - & - & - & 0 & $\mathrm{x}$ & $\mathrm{x}$ & $\mathrm{x}$ & $\mathrm{x}$ & $\mathrm{x}$ & - \\
\hline 3. & Amphiblestrum georgensis Hay. and Thor., 1989 & - & $\mathrm{x}$ & - & - & - & ok & $\mathrm{x}$ & - & - & - & - & +- \\
\hline 4. & Andreella uncifera (Busk, 1884) & $\mathrm{x}$ & $\mathrm{x}$ & $\mathrm{x}$ & $\mathrm{x}$ & $\mathrm{x}$ & $\mathrm{k}$ & - & $\mathrm{x}$ & - & - & - & + \\
\hline 5. & Arachnopusia inchoata Hay. and Thor., 1988 & - & $\mathrm{x}$ & - & - & - & o & $\mathrm{x}$ & $\mathrm{x}$ & $\mathrm{x}$ & - & - & - \\
\hline 6. & Aspidostoma giganteum (Busk, 1854) & $\mathrm{x}$ & $\mathrm{x}$ & $\mathrm{x}$ & $\mathrm{x}$ & - & $\mathrm{k}$ & - & - & $\mathrm{x}$ & - & - & + \\
\hline 7. & Beania inermis (Busk, 1852) & $\mathrm{x}$ & $\mathrm{x}$ & $\mathrm{x}$ & - & - & $\mathrm{k}$ & - & - & $\mathrm{x}$ & - & - & + \\
\hline 8. & Bugula longissima Busk, 1884 & - & - & - & - & $\mathrm{x}$ & o & - & - & $\mathrm{x}$ & $\mathrm{x}$ & $\mathrm{x}$ & - \\
\hline 9. & Caberea darwini Busk, 1884 & $\mathrm{x}$ & $\mathrm{x}$ & $\mathrm{x}$ & $\mathrm{x}$ & $\mathrm{x}$ & $\mathrm{k}$ & $\mathrm{x}$ & $\mathrm{x}$ & $\mathrm{x}$ & $\mathrm{x}$ & - & + \\
\hline 10. & Camptoplites bicornis (Busk, 1884) & - & $\mathrm{x}$ & - & - & $\mathrm{x}$ & o & $\mathrm{x}$ & $\mathrm{x}$ & $\mathrm{x}$ & $\mathrm{x}$ & $\mathrm{x}$ & - \\
\hline 11. & C. asymmetricus Hastings, 1943 & - & $\mathrm{x}$ & - & - & - & $\mathrm{k}$ & $\mathrm{x}$ & - & - & - & - & + \\
\hline 12. & Carbasea ovoidea (Busk, 1852) & $\mathrm{x}$ & $\mathrm{x}$ & $\mathrm{x}$ & $\mathrm{x}$ & $\mathrm{x}$ & $\mathrm{k}$ & - & - & - & $\mathrm{x}$ & - & + \\
\hline 13. & Cellaria clavata (Busk, 1884) & $\mathrm{x}$ & $\mathrm{x}$ & $\mathrm{x}$ & $\mathrm{x}$ & - & $\mathrm{k}$ & $\mathrm{x}$ & - & - & - & - & + \\
\hline 14. & C. malvinensis (Busk, 1852) & $\mathrm{x}$ & $\mathrm{x}$ & $\mathrm{x}$ & $\mathrm{x}$ & $\mathrm{x}$ & $\mathrm{k}$ & $\mathrm{x}$ & - & - & - & - & + \\
\hline 15. & Celleporella allia Hayward, 1993 & - & $\mathrm{x}$ & $\mathrm{x}$ & $\mathrm{x}$ & - & $\mathrm{k}$ & $\mathrm{x}$ & $\mathrm{x}$ & - & - & - & + \\
\hline 16. & C. dictyota Hayward, 1993 & - & - & $\mathrm{x}$ & $\mathrm{x}$ & - & $\mathrm{k}$ & - & $\mathrm{x}$ & - & - & - & + \\
\hline 17. & C. discreta (Busk, 1854) & $\mathrm{x}$ & $\mathrm{x}$ & $\mathrm{x}$ & $\mathrm{x}$ & $\mathrm{x}$ & $\mathrm{k}$ & $\mathrm{x}$ & - & - & - & - & + \\
\hline 18 & Chaperiopsis galeata (Busk, 1854) & $\mathrm{x}$ & $\mathrm{x}$ & $\mathrm{x}$ & $\mathrm{x}$ & - & $\mathrm{k}$ & $\mathrm{x}$ & - & $\mathrm{x}$ & - & - & + \\
\hline 19. & Chaperiopsis patulosa (Waters, 1804) & $\mathrm{x}$ & - & - & - & $\mathrm{x}$ & 0 & - & - & - & $\mathrm{x}$ & $\mathrm{x}$ & - \\
\hline 20. & Cornucopina ovalis Hastings, 1943 & - & $\mathrm{x}$ & - & - & - & $\mathrm{k}$ & $\mathrm{x}$ & - & - & - & - & + \\
\hline 21. & Electra longispina (Calvet, 1904) & $\mathrm{x}$ & - & - & - & - & ok & $\mathrm{x}$ & - & - & - & - & +- \\
\hline 22. & Ellisina antarctica Hastings, 1945 & $\mathrm{x}$ & $\mathrm{x}$ & $\mathrm{x}$ & $\mathrm{x}$ & $\mathrm{x}$ & ok & $\mathrm{x}$ & $\mathrm{x}$ & $\mathrm{x}$ & $\mathrm{x}$ & $\mathrm{x}$ & +- \\
\hline 23. & Himantozoum obtusum Hastings, 1943 & - & - & $\mathrm{x}$ & - & - & 0 & $\mathrm{x}$ & $\mathrm{x}$ & $\mathrm{x}$ & $\mathrm{x}$ & $\mathrm{x}$ & - \\
\hline 24. & Inversiula nutrix Jullien, 1888 & $\mathrm{x}$ & $\mathrm{x}$ & $\mathrm{x}$ & $\mathrm{x}$ & - & $\mathrm{k}$ & $\mathrm{x}$ & $\mathrm{x}$ & $\mathrm{x}$ & - & - & + \\
\hline 25. & Lacerna eatoni (Busk, 1876) & $\mathrm{x}$ & $\mathrm{x}$ & $\mathrm{x}$ & $\mathrm{x}$ & $\mathrm{x}$ & $\mathrm{k}$ & $\mathrm{x}$ & $\mathrm{x}$ & $\mathrm{x}$ & - & - & + \\
\hline 26. & L. hosteensis Jullien, 1888 & $\mathrm{x}$ & $\mathrm{x}$ & $\mathrm{x}$ & $\mathrm{x}$ & - & $\mathrm{k}$ & $\mathrm{x}$ & $\mathrm{x}$ & $\mathrm{x}$ & - & - & + \\
\hline 27. & Menipea patagonica Busk, 1852 & $\mathrm{x}$ & $\mathrm{x}$ & $\mathrm{x}$ & $\mathrm{x}$ & $\mathrm{x}$ & $\mathrm{k}$ & $\mathrm{x}$ & - & - & - & - & + \\
\hline 28. & Micropora notialis Hayward and Ryland, 1993 & $\mathrm{x}$ & $\mathrm{x}$ & $\mathrm{x}$ & $\mathrm{x}$ & - & $\mathrm{k}$ & $\mathrm{x}$ & $\mathrm{x}$ & $\mathrm{x}$ & - & - & + \\
\hline 29. & Paracellaria cellarioides Hay. and Thor., 1989 & - & $\mathrm{x}$ & - & - & $\mathrm{x}$ & o & $\mathrm{x}$ & - & $\mathrm{x}$ & - & - & - \\
\hline 30. & Stomhypsellosaria watersi Hay. and Thor., 1989 & - & $\mathrm{x}$ & - & - & - & o & - & - & $\mathrm{x}$ & $\mathrm{x}$ & $\mathrm{x}$ & - \\
\hline 31. & Talivittaticella frigida (Waters, 1904) & - & - & $\mathrm{x}$ & - & - & o & - & - & - & $\mathrm{x}$ & - & - \\
\hline 32. & Tricellaria aculeata (d'Orbigny, 1847) & $\mathrm{x}$ & $\mathrm{x}$ & $\mathrm{x}$ & $\mathrm{x}$ & $\mathrm{x}$ & $\mathrm{k}$ & $\mathrm{x}$ & - & - & - & - & + \\
\hline 33. & Valdemunitella lata (Kluge, 1914) & - & $\mathrm{x}$ & - & - & - & o & $\mathrm{x}$ & $\mathrm{x}$ & $\mathrm{x}$ & $\mathrm{x}$ & $\mathrm{x}$ & - \\
\hline
\end{tabular}

TF = Tierra del Fuego; Pa = Patagonia; MA = Falkland; BB = Burdwood Bank;

$\mathrm{KG}=$ Kerguelen; $\mathrm{GS}=$ South Georgia; OS $=$ South Orkney; $\mathrm{SS}=$ South Shetland;

$\mathrm{PA}=$ Antarctic Peninsula; $\mathrm{MR}=$ Ross $\mathrm{Sea} ; \mathrm{R}=$ probable migration ways.

$\mathrm{k}=$ To Antarctica; $\mathrm{O}=$ To Magellan area.

species are equally distributed on both sides of the Drake Passage (marked + -). According to Table 5 the real path for migrating species is no doubt the chain of archipelagos stretching between the northernmost tip of the Antarctic Peninsula and the southernmost tip of South America. The actual physical discontinuity along this way, more than the distances between its components, seems to be the Antarctic Convergence passing to the north of South Georgia. Nevertheless it appears that zoaria or larvae of species in Table 5 might endure the thermic change of being in shallow waters to the north or south of the Convergence.

\section{Magellan bathyal and abyssal bryozoan faunas}

Little or nothing is so far known on the Magellan bathyal and abyssal bryozoan fauna. On the western Atlantic side, the continental shelf is huge - measuring ca $1000 \mathrm{~km}$ wide in front of the Falkland Islands - so, most of the collecting records have been obtained in waters of less than $200 \mathrm{~m}$ depth. On the
Pacific side, the continental shelf is much narrower - less than $100 \mathrm{~km}$ - but the continuous bad weather conditions prevent much collecting in outer Chilean Magellan archipelagos. Thus, most expedition activities and collecting records were done in interior waters and not on the continental slope or abyssal plain of that area.

A recent collecting trip by the German research vessel "Polarstern" in 1996 gathered an unusual bryozoan collection from the Magellan continental slope in the Cape Horn area. Two samples containing more than 40 species were obtained at $430 \mathrm{~m}$ and $780 \mathrm{~m}$ depth. One-third of these species are new to science (Moyano, 1997). The collection is dominated by the biomass of flustrine species belonging to several genera and families. The discovery of a living species of Adelascopora, genus considered so far as a Tertiary South American fossil, but at present with two Antarctic species is worth mentioning. DISCUSSION 
Bryozoan diversity in the Magellan zoogeographical Province, with a little over 200 species recorded so far, is similar to that of the Antarctic Peninsula and almost twice the number of species in the Peruvian-Chilean Province. This fact is probably related to the length of coast-line and to the width of the inhabitable submarine associated shelf. Schopf (1978) had already predicted 200 bryozoan species for the Tierra del Fuego and adjacent areas including the Falkland islands. This prediction was based on the available coast as a good indicator of diversity, and on postulates of the island biogeography theory (MacArthur and Wilson, 1967). The large dissected coastline of southwestern South America caused by glaciers during the last million years consists of an enormous number of intricate archipelagos, channels and fjords. To this should be added the broad Atlantic Patagonian shelf which completes the picture of a huge submarine area that explains why the bryozoan fauna is so rich.

The Polychaeta Errantia distribution and species richness along the Chilean coast from Arica to the Magellan region show a somewhat similar pattern to that exhibited by bryozoans. Considering the 184 species indicated by Wesenberg-Lund (1962), it is possible to see an increase of the number of species from north to south: Iquique 30 species, Valparaíso 46 species, Ancud area 62 species, and Magellan region 90 species. The same analysis using the data on distribution and species richness of 167 species of Mollusca Pelecypoda (Soot-Ryen, 1959) shows 81 species from Arica to Valparaíso, 54 species from Valparaíso to Valdivia, 65 species from Valdivia to Golfo Corcovado, and 95 species in the Magellan region. This case is different from that of Polychaeta Errantia because there is a high number of species both in the far north and in the far south, but with higher values in the Magellan region. This trend is supported when considering the total species number of Pelecypoda from Valdivia to the north (90 species) and to the south (120 species). In general terms, the species richness along the Chilean coast increases from north to south as shown by bryozoans, pelecypods and polychaetes; this is probably related to the layout of marine coastal areas as discussed above. It is also probable that such a distributional pattern is evident in other invertebrate groups, however, such analyses are far from the scope of the present study.

The zoogeographical identity of the Magellan region has been widely accepted by many authors (see Briggs, 1974) and confirmed by the results of the Lund University Chile Expedition (Brattström and Johanssen, 1983). This identity is ratified by its $55 \%$ of endemic bryozoan species.

Subantarctic ecosystems, widely connected both latitudinally and longitudinally, differ greatly from that of the Antarctic - almost isolated by the Antarctic Convergence and great marine depths. So, the Magellan region is zoogeographically linked with the circum-austral Subantarctic realm through the West Wind Drift (Hedgpeth, 1969). Along this circum-austral path diverse organisms such as larvae or adults can drift attached to drift-wood, buoys, ships and animals. In this respect it is known that Nothofagus logs coming from South America have reached Macquarie, Marion, South Georgia, South Shetland and South Sandwich islands (Barber et al., 1959; van Zinderen Bakker, 1971; Mathews, 1931; Smith, 1984; Longton, 1977; respectively; fide Burckle and Pokras, 1991).

Another explanation would be to assume a closer proximity of the austral coasts due to a different distribution of lands and seas during the Tertiary (Zinsmeister, 1979). The discovery of South American herbivorous mammals as fossils in Seymour Island, Antarctic Peninsula (Marenssi et al., 1994) suggests that this part of the Antarctic was linked with or much closer to South America and therefore its coasts and faunas of the shelf were also closer. It is also well known that before the Antarctic-South American separation, Australia and Antarctica, as parts of Gondwana, had been drifting apart (GrantMackie, 1979; Durham, 1979), and it is possible therefore that the Antarctic shelf might have functioned as a bridging area between South America and the Australian-New Zealand realm. This statement can be exemplified by the rare and archaic Villicharixa strigosa, among many other bryozoan species inhabiting the inner Magellan sea and New Zealand (Moyano, 1982; Gordon, 1989).

Antarctic-Magellan links are as noteworthy or more so than those of the amphi-Pacific ones. They might have been produced between the southern tip of South America, the Scotia Arc archipelago, western Antarctica and eastern Antarctica. This would explain the existence of not only pairs of vicariant species but groups of congeneric species, such as those of the genera Cellarinella, Smittina, Cellaria, Melicerita, Camptoplites, Notoplites and Arachnopusia. Some bryozoan species such as Camptoplites bicornis probably colonized the Magellan region through the intermission of deep waters because 
species of this genus are both cold stenothermic and eurybathic (Rogick, 1965), thus their presence north of the Antarctic convergence is always in cold deep waters (Hastings, 1943; Gordon, 1989). Another example is the genus Cellarinella which has more than fifteen Antarctic species, but only one, $C$. dubia, stretches from Golfo de Penas $\left(46^{\circ} \mathrm{S}\right.$ in the eastern south Pacific) to the Atlantic Patagonian shelf. The ancestors of this species, inhabiting Subantarctic waters on the shelf, probably reached Patagonian waters following the Scotia Arc path.

\section{ACKNOWLEDGEMENTS}

The author thanks Dr Wolf Arntz of the Alfred Wegener Institut, AWI (Germany), for an invitation to participate in the Joint Italian-Chilean-German expedition to the Magellan Straits on board R/V "Victor Hensen", October 1994. The Dirección de Investigación of the Chilean Universidad de Concepción is also thanked for providing funds of the grant 96.113.039-10 to attend the international workshop IBMANT-97, Universidad de Magallanes, Punta Arenas, Chile, April 1997. The author especially wants to acknowledge Erika Mutschke and Carlos Ríos, Instituto de la Patagonia, Universidad de Magallanes, for providing facilities and bryozoan samples from the Magellan continental slope collected by R/V "Polarstern". The two referees are specially acknowledged because their suggestions have helped to improve the original version of this work.

\section{REFERENCES}

Borg, F. - 1944. The Stenolematous Bryozoa. Further Zool. Res. Swedish Antarct. Exped., 1901-1903, 3 (5): 1-276.

Brattström, H. and A. Johanssen. - 1983. Ecological and regional zoogeography of the marine benthic fauna of Chile. Report No. 49 of the Lund University Chile Expedition 1948-1949. Sarsia, 68: 289-339.

Burckle, L.H. and E.M. Pokras. - 1991. Implications of a Pliocene stand of Nothofagus (southern beach) within $500 \mathrm{~km}$ of the South Pole. Antarct. Sci., 3 (4): 389-403.

Briggs, J.C. - 1974. Marine Zoogeography. McGraw-Hill Book. Co., New York.

Busk, G. - 1884. Report on the Polyzoa - the Cheilostomata. Scient. Res. Challenger Exped., Zool., 10 (30): 1-216.

Cáceres, J. and H.I. Moyano. - 1992. Ancéstrulas y patrones astogenéticos de especies de briozoos marinos chilenos I. Bol. Soc. Biol., Concepción, 63: 27-42.

Cáceres, J. and H.I. Moyano. - 1994. Ancéstrulas y patrones astogenéticos de especies de briozoos marinos chilenos II: Bryozoa del Estrecho de Magallanes. Bol. Soc. Biol., Concepción, 65: 127-142.

Cox, G.W. - 1967. Laboratory Manual of General Ecology. W. C. Brown Co. Publ., Dubuque, U.S.A

Durham, W.J. - 1979. The fossil record, plate tectonics, and devel- opment of characteristic members of austral marine faunas. Proc. Internat. Symp. Mar. Biogeogr. Evol. Southern Hemisphere. N.Z. DSIR Information Ser., 137 (1): 165-186.

Gordon, D.P. - 1984. The marine fauna of New Zealand: Bryozoa: Gymnolaemata from the Kermadec Ridge. N. Z. Oceanogr. Inst. Mem., 91: 1-198.

Gordon, D.P. - 1986. The marine fauna of New Zealand: Bryozoa: Gymnolaemata (Ctenostomata and Cheilostomata Anasca) from the western South Island continental shelf and slope. N. Z. Oceanogr. Inst. Mem., 95: 1-121.

Gordon, D.P. - 1989. New and little-known genera of cheilostome Bryozoa from the New Zealand region. J. Nat. Hist., 23: 13191339.

Grant-Mackie, J.A. - 1979. Cretaceous-Recent plate tectonic history and paleoceanographic development of the Southern Hemisphere. Proc. Internat. Symp. Mar. Biogeogr. Evolut. Southern Hemisphere. N.Z. DSIR Information Ser., 137 (1): 27-42.

Hastings, A.B. - 1943. Polyzoa (Bryozoa) I. Scrupocellariidae, Epistomiidae, Farciminariidae, Bicellariellidae, Aeteidae, Scrupariidae. Discovery Rep., 22: 301-510.

Hayward, P.J. - 1995. Antarctic Cheilostomatous Bryozoa. Oxford University Press Inc., New York.

Hedgpeth, J.W. - 1969. Introduction to Antarctic zoogeography. In: American Geographical Society (ed.): Distribution of Selected Groups of Marine Invertebrates in Waters South of $35^{\circ} \mathrm{S}$ Latitude. Antarct. Map Folio Ser., 11: 1-9.

d'Hondt, J.-L. - 1979. Les Bryozoaires du Secteur Indien de l'Océan Austral. C. R. Soc. Biogéogr. 481: 53-72.

d'Hondt, J.-L. and L. Rédier. - 1977. Bryozoaires récoltés lors des campagnes d'été 1972 et 1974 aux Iles Kerguelen (Ctenostomes, Cheilostomes sauf Cribrimorphes, Entoproctes). Com. Natl. Français Recherches Antarct., 42: 215-236.

Lamouroux, J.V.F. - 1825. Description des polypiers flexibles. In: J. R. C. Quoy and G. P. Gaimard (eds): Voyage autour du monde de l'Uranie et la Physicienne, 1817-1820, Vol. 3, pp. 603-643. Pillet Aîné, Paris.

López-Gappa, J.J. and V. Lichtschein. - 1988. Geographic distribution of the bryozoans in the Argentine Sea. Oceanol. Acta, 11 (1): 89-99.

MacArthur, R.H. and E.O. Wilson. - 1967. The Theory of Island Biogeography. Princeton University Press, Princeton.

Marenssi, S.A., M.A. Reguero, S.N. Santillana and S.F. Vizcaino. 1994. Eocene land mammals from Seymour Island, Antarctica: palaeobiogeographical implications. Antarct. Sci., 6 (1): 3-15.

Moyano, G.H.I. - 1982. Magellanic Bryozoa: some ecological and zoogeographical aspects. Mar. Biol., 67: 81-96.

Moyano, G.H.I. - 1983. Southern Pacific Bryozoa: a general view with emphasis on Chilean species. Gayana Zool., 46: 1-45.

Moyano, G.H.I. - 1991. Bryozoa marinos chilenos VIII: Una síntesis zoogeográfica con consideraciones sistemáticas y la descripción de diez especies y dos géneros nuevos. Gayana Zool., 55 (4): 305-389.

Moyano, G.H.I. - 1992. Bryozoa de la Expedición Italiana al Estrecho de Magallanes, febrero-marzo de 1991: Evaluación preliminar. In: V. A. Gallardo, O. Ferretti and H. I. Moyano (eds.), Oceanografia in Antartide, pp. 509-516. Ediciones Documentas, Santiago de Chile.

Moyano, G.H.I. - 1994a. Bryozoa Microporidae from the southeastern Pacific: two new species and a review. In: J. S. Ryland, P. Hayward and P. D. Taylor (eds.), Biology and Paleobiology of Bryozoans, pp 125-132. Olsen and Olsen, Denmark.

Moyano, G.H.I. - 1994b. Microspora finisterrae sp. n. a new bryozoan species from the Magellan Strait. Bol. Soc. Biol. Concepción, 65: 187-190.

Moyano, G.H.I. - 1995. Bryozoa. In: J.A. Simonetti, M.T.K. Arroyo, A.E. Spotorno and E. Lozada (eds.), Diversidad Biológica de Chile, pp. 163-173. CONICYT, Santiago de Chile.

Moyano, G.H.I. - 1996. Holocene bryozoan links between Australia, New Zealand, Southern South America, and Antarctica. In: D.P. Gordon, A.M. Smith and J.A. Grant-Mackie (eds.), Bryozoans in Space and Time. Proceedings of 10th International Bryozoology Association Conference, pp. 207-219. NIWA, Wellington, New Zealand

Moyano, G.H.I. - 1997. Las especies chilenas de Melicerita (Bryozoa Cellariidae) con la descripción de una nueva especie. Gayana Zool., 61 (1): 49-55.

Rogick, M.D. - 1965. Bryozoa of the Antarctic . Biogeography and ecology in Antarctica. Monogr. Biol., XV: 401-413. 
Schopf, T.J.M. - 1978. The role of biogeographic provinces in regulating marine faunal diversity through geologic time. In: J. Gray and A. J. Boucot (eds.), Historical Biogeography, Tectonics and the Changing Environment, pp. 449-457. Oregon State University Press, Corvallis.

Shannon, C.E. and W. Weaver. - 1963. The Mathematical Theory of Communication. Univ. Illinois Press, Urbana, U.S.A.

Soot-Ryen, T. - 1959. Pelecypoda. Reports of the Lund University Chile Expedition 1948-49. 35. Lunds Univ. Årsskrift N.F., Avd. 2, 55 (6): 1-86.

Wesenberg-Lund, E. - 1962. Polychaeta Errantia. Reports of the
Lund University Chile Expedition 1948-49. 43. Lunds Univ. Arsskrift N.F., Avd. 2, 57 (12): 1-139.

Zinsmeister, W.J. - 1979. Biogeographic significance of the late Mesozoic and Early Tertiary molluscan faunas of Seymour Island (Antarctic Peninsula) to the final breakup of Gondwanaland. In: J. Gray and A.J. Boucot (eds.), Historical Biogeography, Tectonics and the Changing Environment, pp. 349-355. Oregon State University Press, Corvallis. 